\title{
Research on the Integration of Theory and Practice Teaching Material of Information Technology under the Medical Background
}

\author{
WANG Fangzheng ${ }^{1, \text { a }}$ \\ ${ }^{1}$ Jiangsu Vocational College of Medical, yancheng 224005,China \\ awfz4393@163.com@126.com
}

Keywords: Medical test, manage real integration, teaching mode, discussion

\begin{abstract}
Medical laboratory specialty mainly cultivate students by physics, chemistry, biology, computer, and biochemistry, immunology and so on various aspects of knowledge and lab operation technology to all kinds of test specimen, analysis on the human body, in order to obtain the relevant pathogens, pathological changes and human viscera function state information. So this major requires students' high ability of practical operation. At present, under the influence of the traditional teaching mode for a long time, most of the colleges and universities in our country theoretical knowledge and practical skills are not coherent, not cohesion. The author analyzed the real integration of teaching reform in the medical inspection technology professional manager in some of the problems and the accumulation of experience, hopes to provide some references for medical laboratory specialty teaching reform.
\end{abstract}

\section{Introduction}

It is well known that the results of medical tests can be used to assist clinical diagnosis, curative effect observation, prognosis judgment, medication monitoring and patient health assessment, and so on, which are very important for clinical diagnosis. Medical examination is a professional practice ability, it mainly for medical institutions at all levels to train high skilled, high-quality applied talents. At present, although in most universities curriculum related medical test specialty teaching in teaching increased many methods (such as the use of the multimedia courseware, video case teaching method), the school also attaches great importance to the cultivation of students' practical ability, but in the relevant medical knowledge test students, are still in the traditional teaching mode, theory course the experimental class, separate classes, leading to the existence of the disconnection between theory and practice, training of comprehensive ability of graduates with professional inspection job requirement and a certain distance. The integration of theory and practice teaching is that at the same time, the same location and synchronous mode of teaching, classroom and laboratory (workshop) as a whole, teachers teaching the theory and practice guidance teachers as a whole, professional theory and practice as a whole, a kind of teaching mode for students to plan in accordance with the requirements of teachers to determine the subject and learning the special theory and practice. Medical work is a combination of knowledge, skills, responsibility and love, students only learn professional knowledge and professional skills, to provide better services for patients, and the traditional teaching mode of theoretical knowledge and professional skills training separately, leading to the touch, is not conducive to the cultivation of students' occupation quality. To this end, we change the traditional teaching mode, the integration of theory and practice teaching mode in the teaching of professional courses, so that teachers teach and students hands-on integrated teaching process in the cultivation of students closely, ability pay attention to its occupation quality. The so-called integration is to organize the teaching system, combining the teaching link of the theory and practice of cultivating students' occupation ability of combining teaching as a whole, separate teaching plan and syllabus construction occupation ability overall training target system, to ensure the realization of the overall objectives through each 
teaching link of implementation. The new Chinese since the reform and opening up, the rate of change of occupation technology has far exceeded the rate of development of occupation education and training, occupation education training is far behind the occupation technology changes, occupation school can not be timely and quickly cultivate technical talents to adapt to the adjustment of industrial structure, the rapid development of social economy. This contrast has seriously hindered the sustainable development of enterprises, economy and society. Therefore, in order to improve the quality of teaching and to train qualified skilled personnel, it is necessary for vocational schools to adopt integrated teaching.

\section{The Significance of Integration of Theory and Practice Teaching}

Integrated teaching, popular understanding is to integrate theory teaching and practice teaching. It broke the discipline system and the traditional teaching mode, according to the occupation education objectives of the integration of teaching resources, embodies the "ability standard" principle, and gradually realize the 3 changes: one is from teacher centered to student-centered transformation, the second is from the textbook centered to the teaching syllabus and training center the third is to shift from the classroom as the center to the center for change in the training room. This teaching model can better solve the problem of disconnection between theoretical teaching and practical teaching, enhance the audio-visual teaching, fully reflect the main role of students, and help to improve the quality of teaching. Give full play to the main role of students, improve students' interest in learning. The traditional teaching model is based on the teacher as the main body, and the students passively and passively accept knowledge. The integration of theory and practice in teaching methods is based on skills training, with the relevant theoretical knowledge of the teaching module, and by one or more teachers at the same time as theoretical teaching and practice guidance. Students to study music, pleasure in learning, change from passive learning to active participation, active in the classroom atmosphere, and foster students' ability to analyze and solve practical problems, which greatly improves the students' interest in learning, cultivate students' innovative spirit and creative ability. Improve the quality of personnel training, and gradually achieve zero distance employment. Through the organic combination of theory and practice, and even school can cooperate with the hospital, let the students experience the real medical examination, need to go through the school talents to better meet the needs of the society. Medical laboratory professional integration of theory and practice teaching for students in the simulation of the hospital (Laboratory) environment, advance to experience the workplace environment, understand the actual work of the required knowledge and skills and occupation quality, let the students learn more purpose and pertinence in theoretical knowledge and learn the skills required for employment in the future, improve their employment competitiveness, and gradually realize zero distance employment, let the employer satisfaction. Promoting teachers' professional development and improving their practical teaching ability. The implementation of the integration of theory and practice in medical examination requires teachers not only to have a wealth of theoretical knowledge, but also have strong practical ability.

\section{Construction of Integrated Teaching Measures}

After several years of exploration, our school in promoting integrated teaching specific practices are: to create a good atmosphere for the implementation of integrated teaching. The implementation of integrated teaching model, involving a wide range, is not only a few people can be completed in a short time, must be through the joint efforts of all teachers and students, concerted efforts, in order to implement the integration of teaching. On the one hand, the resistance of integrated teaching is mainly from the teaching habits that teachers have developed for a long time; in addition, the understanding of the importance of integrated teaching is also very critical. Therefore, the level of teachers, our school launched the first integrated teaching seminars, workshops, fully aware of the importance of integrated teaching; for the student level, pay more attention to students in thought, specific examples through the form of employment education, enterprise information feedback, 
previous graduates, make students understand the importance of occupation and skill occupation quality. Taking various measures to promote integrated teaching. The integration of teaching practice teaching and theory teaching together organically, reflects the advanced teaching idea, let students "learn to know, learn to do, learn to live, learning to live together", which can make students master the necessary skills and theoretical knowledge, and can make the students consciously to learn the theory and practice also, can cultivate students' entrepreneurial ability and innovation ability. In order to train high-quality and highly skilled talents, our school actively adjusts the train of thought of running schools, increases investment, constantly improves comprehensive training places, adopts various measures, and vigorously promotes the "integration" teaching. Training "double qualified" teachers to adapt to integrated teaching. The first condition for implementing integrated teaching is teachers. Integrated teaching needs "double qualified" teachers, no "double qualified" teachers, theory and practice are fragmented. "Double qualified" teachers must have comprehensive professional ability, and can solve the practical problems in production.

\section{Some Problems in the Implementation of Integration of Theory and Practice}

The integration of theory and practice is insufficient, and the teaching method of integration of theory and practice emphasizes multiple tasks of teaching in the same site and at the same time. It is necessary to have the hardware equipment and learning environment suitable for the specialty and scale. Due to various factors and constraints, lack of many higher vocational colleges of the integration of theory and practice teaching field, such as professional courses, classes can only be arranged in a small class simulation laboratory, there will be the integration of theory and practice teaching field stress, dysfunctional phenomenon in English teaching. The school based teaching material of integration of theory and practice needs to be compiled and perfected. Teaching materials are the main basis and information source of teachers' lectures and students' learning. It is difficult to achieve good integration teaching without good integrated teaching materials. Traditional teaching materials have been unable to meet the needs of integration of theory and practice. Lack of instruments and equipment for medical examination. Many inspection items of medical inspection are tested by medical inspection instruments. However, due to the relatively simple source of funds in schools, most schools have a shortage of funds. On the other hand, most medical laboratory instruments are expensive, so it is often difficult for schools to fully equipped with instruments and equipment used in the hospital laboratory. In the operation of medical testing equipment in the course of their practice, often several students in a group with a single instrument, coupled with the limited classroom time and other factors, will lead to the students can not master the use of the instrument, then the end of course. The lack of instruments and equipment will reduce the teaching quality of integration of theory and practice. Teachers' professional ability and sense of responsibility need to be strengthened. The integration of theory and practice requires teachers not only to have rich professional knowledge, but also to have skilled operation skills, not only can be competent for theoretical teaching, but also can guide the practice operation. However, some teachers in higher vocational colleges are restricted by various conditions, and the level of practical operation ability needs to be further improved, and the sense of responsibility for teaching should be further strengthened. If in the process of teaching, teachers think that since the integration of theory and practice teaching, mainly embodies the main role of the students, is to let the students own more hands-on, the teacher himself sitting on the side of busy with their own things, no, this is not true of the integration of theory and Practice teaching. The school teaching evaluation system needs to be adjusted accordingly. The traditional evaluation methods in schools are often the evaluation of students' theoretical knowledge. The standard of this evaluation is relatively simple, and the final results are one-sided, and it is not conducive to the integration of theory and practice teaching reform. By the way of evaluation, often only have an understanding of the students' mastery of theoretical knowledge and practical operation, to grasp the extent of it can only reflect the degree of student learning is absolutely ignorant of, one-sided, but not on students' comprehensive understanding of the situation to do a check. 


\section{Strategies and Measures for Problems in Teaching}

The integration of theory and practice teaching is in accordance with the rules and characteristics of occupation education, to adapt to a successful teaching method of students' occupation school foundation at present and physical and mental development, suitable for professional courses of laboratory medicine teaching, worthy of promotion. I think we can take the following measures to change the teachers' teaching concept and improve teachers' professional ability: first, the school to the integration of theory and practice teaching mode of publicity, not regularly carry out to observe the integration of theory and practice teaching, teachers invited to lecture, let the teachers really feel good effect of the integration of theory and practice teaching. Second, schools should strengthen the training of double quality teachers, and give policy support, financial support and incentive measures to promote the professional promotion of teachers in the integration of theory and practice. Third, teachers should be based on the existing experimental conditions of the school and their own situation, combined with the requirements of the post graduates, and actively compile applicable and operable integration of theory and practice teaching materials. Fourth, teachers should enhance their sense of responsibility, teach students civilized norms, safe operation knowledge and skills, maintain good classroom order, orderly, targeted. Adjusting the teaching evaluation system of the school. On the basis of the nursing professional talent demand and survey of graduates results through extensive cooperation, visited the hospital, according to the analysis of the corresponding social professional occupation, determination of nursing graduates jobs, summed up the work should have the ability and quality, and get into these positions the ability and quality of learning field curriculum, training mode of construction, form the talent training scheme. The occupation ability as the core, pay attention to the cultivation of sustainable development ability and innovation ability, the typical tasks as the carrier, the working process of the system as the goal, the construction of theory and practice integrated teaching mode and curriculum system. According to professional characteristics, in accordance with the working process of the professional core courses of basic nursing skills, health evaluation and surgical nursing technique is divided into several typical task modules, mainly in the course of knowledge and skill points into the task module, to the project as the main line, the arrangement module teaching, strengthening skill training. The theory of teaching teaching content embedded practice, basic operation training as the basis, appropriate to increase the comprehensive training project, realize the school distance, make students grasp knowledge and skills in the process of completing the task. Before and after the curriculum closely around the ability requirements, form an organic whole. The nurse and nursing occupation standard as the basis, change the theory and practice of two yuan from the status quo, task driven, project oriented, classroom and training integration teaching mode to realize the integration of location, teaching theory and practice. The teaching practice process, practice teaching and theory teaching hours is more than $1: 1$.

\section{Conclusion}

The author thinks that the teaching of medical laboratory specialty is suitable for the teaching mode of integration of theory and practice. This is a task, project as the carrier, both teachers and students while teaching, learning, doing, theory and practice alternately, have real reason, real right, to highlight the cultivation of students' practical ability and professional skills, teaching methods and arouse the students' interest in learning, in accordance with the rules and characteristics of occupation education. But in the implementation of integration of theory and practice in the teaching process also encountered some problems, puts forward some strategies and measures to some person, hope to provide some reference to the teaching reform of medical laboratory professional integration of theory and practice. The traditional teaching mode is to separate theoretical teaching from practice teaching. First, learning theoretical knowledge, then concentrating practice, separating theory from practice, it is not suitable for the needs of current higher vocational education. In the vigorous development of vocational education today, actively implement the integration of theory and practice teaching mode for higher vocational talents 
training is very necessary. The integration of theory and practice shows its rationality in this respect. First of all, the transfer of teaching information is synchronous, imparting knowledge, skills training and ability training into one organic combination, synchronous. Secondly, it ensures the identity of teaching information, avoids the misunderstanding of students in cognition and practice, and provides the guarantee for the optimization of teaching. The integration of theory and practice can fully cultivate students' innovative ability, design scientific training situation, and let students collect, analyze and deal with them through themselves.

\section{Acknowledgements}

Research on the integration of theory and practice teaching material of information technology under the medical background. School level research project:Y201619.

\section{References}

[1] H.J.C. Discussion on the teaching model of integration of theory and practice in Higher Vocational Colleges [J]. Higher Education research, 2012,02.

[2] M.Z.L. Reform and practice of modular teaching of "integration of theory and practice" in pediatric nursing[J]. Nursing and Rehabilitation, 2011,06.

[3] L.J.C. Integrated teaching model of theory and practice in instrumental analysis course [J]. Vocational Education Research, 2010,08.

[4] L.Y. Z, R.Y, X.B.L, L.L.Q, P.Z. Food quality and safety specialty Research on integrated teaching model of theory and practice in instrumental analysis course [J]. Heilongjiang science and technology Information, 2013,01.

[5] Y.H.W. Innovation of teaching mode of Higher Vocational and technical education. Discussion on physical teaching mode [J]. transportation vocational education, 2011,06.

[6] D.S.T. research and Practice on the construction of practice teaching system of "teaching, learning and doing"[J]. Education and Profession 33 period of 2008. 